Antropologia 



\title{
Ação indigenista, eticidade e o diálogo interétnico
}

\author{
ROBERTO CARDOSO DE OLIVEIRA
}

\begin{abstract}
A S CONSIDERAÇÕES que pretendo desenvolver tomarão por base um conjunto de tópicos sobre os quais venho refletindo continuamente nesses últimos anos. Como são tópicos que se relacionam com a questão indigenista, visando especificamente suas práticas e o quadro moral que as contém, achei que não seria descabido retornar a eles nesta oportunidade, ainda que muitas das idéias que aqui apresentarei possam ser do conhecimento de parte do auditório, particularmente de meus colegas antropólogos, uma vez que elas têm sido aventadas em diferentes oportunidades, seja através de artigos, seja em conferências como esta. Mas para um público bastante diversificado e multidisciplinar como este, sempre presente nas reuniões da SBPC, tenho a esperança de poder contar com o seu interesse sobre as questões de que tratarei a seguir: a da ação indigenista, a da eticidade e a do diálogo interétnico.
\end{abstract}

Inicialmente, porém - e com vistas a construir o meu argumento -, procurarei relacionar algumas questões teóricas, como as que se referem à "ética discursiva" e nos termos pelos quais a entendem autores como Apel e Habermas, com práticas geradas na esfera de uma política pública, de governo, porém aplicando essas questões teóricas a um conjunto de problemas bastante concretos que parecem estar intimamente relacionados com a necessidade, cada vez mais premente, de se efetivar uma ação indigenista crítica, a condição de ser, preliminarmente, autocrítica; mas mais do que isso, a se tomar por referência uma "ética crítica" na forma pela qual ela se constituiria a partir das vitimas - certamente vítimas históricas, em se tratando de povos originários. É portanto nesse espaço que se situa a questão indigenista: i.é, a da relação sempre crítica, no sentido de difícil e complexa, entre o Estado e as etnias indígenas em terras das três Américas - e de uma maneira toda especial no Brasil. Cabe esclarecer ainda, quanto ao uso do termo indigenista, que ele possui uma larga tradição na América Latina, instituída pela ação do Instituto Indigenista Inter-Americano, esse órgão da “Organização dos Estados Americanos” (OEA), ao qual cabe observar as políticas estatais do hemisfério destinadas aos povos indígenas. O I.I.I., como é conhecido, está sediado no México desde 1940, ano de sua fundação, o 
que confere ao uso do termo uma tradição institucionalizada de mais de meio século. É assim que, como uma modalidade de atuação governamental, considero que a política indigenista deva ser capaz de auto-avaliar-se sistematicamente com vistas a atender aos requisitos mínimos de uma ética, antes de pautar-se exclusivamente por motivações políticas, ainda que sejam políticas públicas, conduzidas pelos Estados nacionais. Isso significa que antes de atender aos preceitos de Considero que a política uma política democrática, por mais correta que seja, é de se esperar que atenda aos imperativos de uma étiindigenista deva ser capaz de auto-avaliar-se ... ca: uma ética que possa ser reguladora das relações entre os povos indígenas e o Estado-nação. Quanto à política e/ou políticas propostas pelos próprios índios e por suas lideranças, elas serão mencionadas como politicas indigenas - expressão que dispensa qualquer esclarecimento adicional.

O primeiro problema a que me referi - o da ação indigenista -, diz respeito a uma modalidade de desenvolvimento alternativo (i.é alternativo aos modelos desenvolvimentistas) denominado "etnodesenvolvimento", na forma pela qual essa modalidade foi proposta como política recomendada pela "Reunião de Peritos sobre Etnodesenvolvimento e Etnocídio na América Latina" realizada em San José da Costa Rica em 1981, sob os auspícios da Unesco (1). É uma política que desde então tem sido difundida em diferentes latitudes do planeta como uma espécie de solução para um processo de desenvolvimento que não colida com os interesses e os direitos de populações ou povos alvos de programas de mudança induzida. O segundo problema - o da eticidade - está relacionado com o que se poderia chamar de organização do campo político indígena, i.é não-indigenista, como condição de possibilidade de um verdadeiro diálogo entre lideranças indígenas que efetivamente sejam admitidas como representantes de seus respectivos povos e que venham a poder instituir, por consenso negociado junto ao Estado, as regras de uma interlocução aberta e democrática. O terceiro, e último problema - o da especificidade do diálogo interétnico -, refere-se às dificuldades encontradas na atualização da própria ética discursiva em amplos espaços interculturais, como soem ser os que envolvem as relações dialógicas entre os povos indígenas e o Estado nacional, isto é, no macroespaço de interseção das políticas indígena e indigenista. Esses três problemas, por suas diferentes naturezas, permitirão algumas reflexões que considero relevantes para o equacionamento da questão ética neles presente, porém nem sempre considerada como merecedora de nossa atenção. 


\section{As pré-condições ao diálogo argumentativo}

Antes de examinarmos os três problemas há pouco enunciados, gostaria de expor aquilo que entendo como sendo as pré-condições de um diálogo que seja efetivamente democrático, ademais de obedecer aos imperativos de uma ética. Para tanto vale recorrer - e de um modo bastante sumário - a uma das teorias que considero mais adequada para o entendimento dessas pré-condições. Recorro à teoria de Apel - há pouco referido -, atendo-me entretanto apenas àquilo que diz respeito ao uso que dela farei no desenvolvimento das considerações a seguir e que dizem respeito a dois conceitos que me parecem centrais em sua teoria: o de comunidade de comunicação e o de comunidade de argumentação. Procurarei mostrar que eles são estratégicos para o encaminhamento de minha própria argumentação. Penso que será suficiente dizer que uma "comunidade de comunicação" é uma instância constitutiva de qualquer tipo de conhecimento, inclusive o conhecimento científico. É uma instância marcada pela intersubjetividade, inerente por sua vez a toda "comunidade de argumentação" - esse segundo e importante conceito apeliano. Vemos portanto que os conceitos de comunidade de comunicação e de comunidade de argumentação são coextensos; significando que tais comunidades estão constituídas tanto por elementos (i.é indivíduos) de um grupo cultural qualquer, quanto por elementos de um determinado segmento profissional (científico, técnico ou administrativo) de uma mesma sociedade, desde que estejam inseridos num mesmo "jogo de linguagem" ou em um mesmo subsistema cultural (2).

Para ilustrar isso, tomemos como caso limite uma comunidade profissional bastante sofisticada como, por exemplo, uma dessas comunidades formadas por cientistas como as que se reúnem em eventos como este da SBPC. Apel vai dizer que a validade lógica dos argumentos formulados no interior de comunidades desse tipo pressupõe necessariamente um acordo intersubjetivo em torno de regras explícitas ou tacitamente admitidas. Isso quer dizer que mesmo em uma comunidade de cientistas se observa uma exigência de consenso em torno de normas e de regras subjacentes ao diálogo interno a essa comunidade e que podem ser, no limite, as da própria lógica formal. Tais regras passam a ser aquelas que devem prevalecer no exercício da argumentação entre seus membros - uma argumentação voltada para a busca de consenso. E a garantia de um tal consenso está, precisamente, na existência de uma ética que seja intersubjetivamente válida e que signifique o dever daqueles cientistas, membros dessa mesma comunidade, em obedecer às regras e às normas instituídas por aquele consenso, portanto fruto de um processo de livre negociação entre os indivíduos componentes de uma determinada comunidade de comunicação. Pois bem: se isso é 
verdadeiro para uma comunidade de cientistas, igualmente é para qualquer outra comunidade de comunicação e de argumentação no interior da qual se constrói todo e qualquer conhecimento. Essa é uma idéia que temos de levá-la em conta, uma vez que ocupa um lugar central nos argumentos que pretendo apresentar no desenvolvimento desta exposição.

A ocorrência de um acordo tácito - i.e. não anteriormente negociado pode ser observada em sistemas culturais, possuidores de características diversas daquelas observáveis em comunidades de cientistas, técnicos ou administradores. Já as comunidades de comunicação constituídas por indivíduos membros de segmentos sociais, tais como as classes ou as etnias, guiadas exclusivamente pelo senso comum ou por ideologias de classe ou étnicas - valha o exemplo -, os acordos com relação às normas instituídas tendem a ser naturalizados, portanto jamais sujeitos à reflexão. Assim, em comunidades de comunicação desse tipo os seus membros tendem, num extremo, a se assumirem com um alto grau de etnocentrismo; já num outro extremo, por sua vez, sempre se poderão constatar coletividades, como certos grupos étnicos, por exemplo, no interior dos quais é possível identificar segmentos altamente alienados, destituídos de um consenso mínimo capaz de fazê-los "pensar em grupo", isto é, que obedeçam a regras intersubjetivamente aceitas. Esse fenômeno de alienação identitária, que chamei certa vez de "caboclismo", pude examiná-lo na pesquisa que realizei com os índios Tükúna no alto rio Solimões, no estado do Amazonas (3) e que se mostrou ser uma categoria social estratégica para a interpretação de identidades limite: entre ser e não ser índio. Todavia, o que desejo sublinhar quando me reporto aos conceitos de comunidade de comunicação e, sobretudo, ao de comunidade de argumentação, é a existência de um espaço social marcado por relações dialógicas. A saber, que tenham lugar no plano da linguagem, do discurso: são relações que tanto estão presentes no diálogo interpares de uma comunidade profissional, como no diálogo entre membros de uma comunidade cultural, a exemplo do que pode ocorrer no interior de uma determinada etnia. O pressuposto sobre a viabilidade desse diálogo e, por conseguinte, a inteligibilidade do mesmo entre interlocutores, está na observância de um acordo intersubjetivo em torno de normas e de regras - explícitas ou implícitas, volto a dizer. Em suma, a observância de uma ética, aqui entendida como o dever de obediência às normas instituídas por consenso: a noção de eticidade recobre precisamente isso! Entretanto, para que essas relações dialógicas ocorram num plano simétrico entre os interlocutores - indivíduos ou grupos - e mantenham um diálogo livre, sem a dominação de um interlocutor sobre outro, elas devem se dar num espaço substancialmente democrático ou, pelo menos, democratizável. É o que nos instrui a teoria habermasiana da "ética discursiva" quando, em sua crítica à dimen- 
são idealista da hermenêutica de Gadamer, observa a necessidade de se ter em conta o caráter democrático ou autoritário da interlocução, portanto o poder em que está investida a autoridade da tradição, não considerada nesses termos pelo filósofo hermeneuta. Nesse sentido, pode-se dizer grosso modo que Habermas, com sua crítica a Gadamer, complementa a teoria de Apel (4). Para me restringir ao tema que estou desenvolvendo gostaria de examinar o problema da interlocução democrática e da argumentação no contexto de certas práticas interétnicas, como as mencionadas no início e que estão relacionadas com a questão indigenista.

\section{Etnodesenvolvimento e ação indigenista}

Estabelecido o enfoque que pretendo dar às questões concretas sobre as quais tentarei conduzir algumas reflexões, passemos a elas, primeiramente tratando da relação entre a ação indigenista e o etnodesenvolvimento. Recorro aqui a Rodolfo Stavenhagem e a elaboração que fez da teoria de etnodesenvolvimento, como um dos modelos possíveis de desenvolvimento alternativo (5), em tudo e por tudo oposto à ideologia desenvolvimentista, normalmente portadora de posturas contaminadas de autoritarismo. Depois de haver sido o verdadeiro inspirador da Reunião realizada em Costa Rica, há pouco mencionada, Stavenhagen escreveu um interessante artigo sobre o assunto, cuja tradução pudemos publicar no Anuário Antropológico (Stavenhagem, 1985). Esta não é a primeira vez que me valho do conceito de etnodesenvolvimento (Cardoso de Oliveira, 1990); porém, diferentemente de Stavenhagem, procurei associá-lo à questão da eticidade; como sabemos, uma questão que diz respeito à expectativa de obediência a normas instituídas intersubjetivamente, implicando, portanto, o dever de cumpri-las pelas partes envolvidas no diálogo interétnico. Pude observar, então, que a questão ética, ainda que não enfrentada por Stavenhagem, já estava pressuposta no espírito de seu texto quando aludia a pelo menos dois aspectos do modelo de etnodesenvolvimento: o que diz respeito à necessidade de adoção de uma "visão interna ou endógena" pelos responsáveis de um programa de mudança social induzida, a saber, que leve em conta o discurso nativo, seja ele indígena, camponês ou outro qualquer que expresse as expectativas de setores da sociedade alvo de projetos de etnodesenvolvimento; outro aspecto, este carregado de eticidade, seria aquele relativo à indispensabilidade de participação daqueles povos, alvos da mudança induzida, nas diferentes etapas de "planejamento, execução e avaliação" dos programas de etnodesenvolvimento. Em verdade, Stavenhagem se inspira na realidade étnica de países hispano-americanos, possuidores de populações indígenas de grande expressão demográfica, como Bolívia, Guatemala, Peru e Equador, todos com mais de $40 \%$ de indígenas (alcançando nos dois 
primeiros cerca de 70\%), ou mesmo em países com contingentes indígenas menores, como México, Chile, Honduras e Belize que ficam entre $5 \%$ a $20 \%$ do total da população nacional respectiva. Não obstante, o conceito de desenvolvimento alternativo proposto é suficientemente amplo para se adequar ao etnodesenvolvimento mesmo quando aplicável em países como Brasil ou Nicarágua, sabidamente detentores de reduzidos contingentes demográficos indígenas. Por conseguinte, essa não seria a razão para inviabilizar a adequação desse modelo alternativo junto à realidade brasileira e não exclusivamente - é preciso enfatizar - apenas aos povos indígenas do território nacional. $\mathrm{O}$ que significa dizer que esses programas alternativos poderão ser igualmente úteis e, sobretudo, éticos, junto a quaisquer outros grupos carentes de auxílio para o seu desenvolvimento, sejam eles constituídos por operários urbanos, por favelados, por aldeões e ou por qualquer segmento

\section{Estimular mudanças} pela via do entendimento minoritário e subalterno da sociedade brasileira, sempre ameaçados de se torentre as partes ... narem vítimas de programas desenvolvimentistas geralmente não comprometidos com os seus interesses. Todavia, o problema que se põe agora - e que eu gostaria de destacar, e aqui me concentro nas populações indígenas - é o de como implementar um processo de etnodesenvolvimento que, certamente, envolverá uma interação entre a(s) etnia(s), objeto de transformação sócio-econômica, e setores técnicos, administrativos e políticos da sociedade global, sem violentar os requisitos de moralidade. O caráter participativo das populações alvos desses programas, conforme exige o modelo de etnodesenvolvimento, já indica claramente ser ele um pré-requisito indispensável se se deseja estimular mudanças pela via do entendimento entre as partes, o que significa dizer pelo caminho da negociação. Mas vamos aprofundar um pouco mais nossas reflexões sobre a dimensão ética de uma negociação que possua indiscutível legitimidade moral.

O ponto de partida para essa reflexão, levando-se em conta as considerações precedentes, estaria no encaminhamento do seguinte problema: considerando-se que as decisões relativas a um programa de etnodesenvolvimento devem ser tomadas em nível de uma comunidade de comunicação e de argumentação, o que seria essa comunidade e qual a natureza do saber que os seus componentes partilhariam? Se o modelo já está a indicar que a participação da população alvo nas diferentes etapas do processo de etnodesenvolvimento é condição de sua exeqüibilidade, parece ficar evidente que isso implica o reconhecimento de uma comunidade de comunicação de natureza interétnica. Implica igualmente que subjacente ao con- 
ceito de etnodesenvolvimento - se quisermos considerá-lo em termos de seu conteúdo ético - está uma comunidade de argumentação. Claro que não se trata de uma comunidade de argumentação interpares, em sua acepção apeliana como a que tem lugar no interior de um grupo profissional de cientistas, como no exemplo dado anteriormente, porém entre grupos e indivíduos portadores de culturas distintas, como ocorre tipicamente nas relações interétnicas. Para ilustrar isso, diríamos que o encontro entre uma equipe de indigenistas (formada por antropólogos, técnicos e administradores) e lideranças indígenas, consistiria uma comunidade real de comunicação, no interior da qual se daria o diálogo tendente a gerar - pelo menos em teoria (como pressupõe o conceito de comunidade $i d e a l$ de comunicação) - um acordo intersubjetivo em torno de regras mínimas suscetíveis de assegurar um fluxo recíproco de idéias formuladas pelas partes.

Seria de se esperar, em primeiro lugar, que os responsáveis pela ação indigenista estivessem naturalmente imbuídos dos princípios do etnodesenvolvimento (6) e, portanto, procurassem dialogar com as lideranças locais sobre seus desejos de mudança. Em segundo lugar, a direção que essa mudança poderia tomar só seria

dialogar com as lideranças locais sobre seus desejos de mudança ... descoberta como resultado da interlocução que deveria ocorrer necessariamente no interior de uma comunidade de comunicação transformada em comunidade de argumentação, onde a troca de idéias estará baseada em argumentos. Não será difícil imaginar que em termos cognitivos estaria ocorrendo o que os hermeneutas chamam de "fusão de horizontes", onde o tipo de "verdade" alcançável pela comunidade intercultural seria produto de uma "negociação" entre as partes. Nesse sentido, o pressuposto ético fundamental é que essa negociação só pode ter lugar no âmbito de relações simétricas, o que significa dizer: livres e democráticas, capazes de estabelecer, numa primeira etapa, regras claras, acordadas por consenso explícito entre os interlocutores de ambos os lados. O não ferir a ética começaria por não romper as regras preliminares de entendimento. Desde logo, em lugar de confronto étnico - algo corrente nos programas desenvolvimentistas - haveria de se esperar um encontro entre interlocutores imbuídos menos de verdades e mais de pontos de vista. Mas seria de se esperar também que a responsabilidade moral de viabilizar a interlocução estaria nas mãos do setor indigenista, convencido - por seu lado - do espírito e, em conseqüência, dos princípios do etnodesenvolvimento. Constata-se assim que essa modalidade de desenvolvimento alternativo embora não deixe de se constituir em uma estratégia de mudança 
social induzida, ela opera sob condições concretas bem diversas daquelas que sustentariam os projetos tradicionais desenvolvimentistas. E a condição principal estaria na observância desses pressupostos éticos que acabo de examinar, cabendo incluir ainda o alienígena - o não índio - estar aberto ao horizonte do Outro: ao do indígena. Gostaria de ilustrar isso com a fala de uma liderança Náuatl, de Natalio Hernández, um intelectual indígena mexicano, quando se manifesta sobre o etnodesenvolvimento, entendendo-o como a capacidade que tem um povo para planejar e desenvolver o seu próprio projeto histórico no interior de um país como o México. Falando como representante da "Organização de Profissionais Indígenas Náuas", diz que sua organização se apoia em quatro princípios, que também chama de raízes, e que constituem as bases de uma interlocução possível no quadro do etnodesenvolvimento. São princípios para os quais os interlocutores do pólo dominante, provavelmente técnicos do Instituto Nacional Indigenista (INI) mexicano, deveriam estar abertos à compreensão dos mesmos como condição para o diálogo interétnico. Vejamos os quatro princípios: 1. a Unidade Náuatl, "que permitirá realizar e apoiar ações concretas na arte, na produção e na educação"; 2. o Sentimento de Fraternidade, como "o reconhecimento de que todos os indígenas do México são irmãos e por isso se propõe desenvolver e consolidar o princípio de fraternidade étnica e interétnica, o que envolve todos os povos da terra"; 3. a Raiz Antiga, como capaz de "recuperar o (...) próprio rosto" do povo Náuatl, resgatando suas origens, pois "sabendo quem somos - diz ele - e de onde viemos podemos enriquecer a nossa vida presente e construir um melhor futuro para nossos filhos". E aqui uma afirmação interessante, como a demonstrar que a aceitação da cidadania mexicana não colide com a afirmação de sua identidade Náuatl: "Desta maneira - continua - contribuiremos ao fortalecimento de nossa identidade nacional como mexicanos"; 4. a Palavra dos Anciãos, uma vez que "nossa memória histórica e cultural - prossegue em sua fala - se preservou (...) [juntamente] com nossos princípios essenciais que regem a vida cotidiana de nosso povos náuas, [como] o respeito aos maiores, o respeito à natureza, o amor ao trabalho, o sentimento comunitário, tudo isso se mantém vivo através (...) da palavra de nossos anciões, uma das fontes ou raízes fundamentais para cimentar nosso desenvolvimento" (Hernández, 1990: 68). Vejo nas palavras de Hernández a transcrição da face Náuatl, como oferecendo os termos ou as bases sobre as quais a negociação prevista no modelo do etnodesenvolvimento poderia ser realizada. Pareceu-me por isso ser um bom exemplo, pois nos mostra o que poderia ser considerado - pelo menos no caso dos Náuas - como o que seria para eles as condições ou os pré-requisitos de uma negociação intercultural. Todavia, voltarei a abordar mais adiante a questão do diálogo interétnico, ocasião em que me 
deterei nas dificuldades concretas de sua efetivação plenamente democrática e ética. Antes, creio ser necessário examinarmos mais detidamente sobre as reais possibilidades de um diálogo interétnico em âmbito nacional, especificamente o Brasil.

\section{Possibilidade de organização do campo político indígena}

Se considerarmos o modelo do etnodesenvolvimento como sendo eficaz na promoção do diálogo interétnico em nível micro e transportarmos o modelo para o nível macro, veremos que a situação vivida pelas partes torna-se extremamente mais complexa. No modelo de desenvolvimento alternativo tratava-se de colocar frente a frente representantes do Estado - no caso brasileiro a FUNAI - e a ou as lideranças de tal ou qual comunidade indígena alvo de mudança induzida. Todavia, já no caso de formulação e aplicação de uma política pública em nível nacional, como assim é pensada uma política indigenista, a grande dificuldade é a identificação de interlocutores possíveis no interior do campo indígena. Quem representa quem? O que se sabe é que ao longo da história recente do movimento indígena no Brasil, iniciado nos anos 70, como eco do que ocorria em alguns pontos do continente americano, a se destacar o chamado "red power" estadunidense, esse movimento não teve a resposta que se poderia desejar do Estado, numa época dominada pelo governo autoritário que surgiu do golpe militar de 64 e radicalizou-se em 68, com o Ato Institucional $n^{\circ} 5$. O governo de então não levou em consideração um movimento social que geraria a "União das Nações Indígenas" e, posteriormente, dezenas de outras organizações que começariam a surgir no bojo desse mesmo movimento. A levarmos em conta um recente levantamento das associações e organizações indígenas, estima-se que quase 300 delas foram criadas nessas últimas décadas (7). Claro que elas são de vários tipos, desde as locais e/ou regionais até as que aspiram ser representantes nacionais; como também aquelas exclusivamente originárias de grupos indígenas; ou ainda as que surgiram na sociedade civil em apoio às demandas indígenas. Como interpretar essa proliferação de entidades não-governamentais? Entendo isso como uma tentativa de inserção dos povos indígenas na própria sociedade civil e apoiados por essa mesma sociedade através de uma certa variedade de ONGs. Esse associativismo vem demonstrar, por outro lado, que existe um potencial de mobilização política dos povos indígenas que um Estado democrático não pode ignorar. Todavia, o que vimos com a redemocratização do país, salvo algumas exceções de autoridades indigenistas regionais (mas que confirmam a regra), foi a permanência daquela mesma atitude de ignorar as organizações indígenas 
sem considerá-las como podendo se constituir nos mais adequados interlocutores diante desse mesmo Estado. Não há dúvida que o Estado não só poderia como deveria - em meu modo de ver - contribuir para fortalecer o campo indígena (no sentido de campo político), inicialmente pelo reconhecimento de suas organizações para, posteriormente, empreender conversações com seus líderes para negociarem as normas pelas quais a interlocução entre o campo indígena e o campo indigenista poderia ser conduzida. Inclusive contribuindo inicialmente com recursos financeiros de modo a assegurar deslocamentos de seus líderes de uma região para a outra, pois o que se tem observado na prática dessas organizações é a privatização dessas ajudas, seja por meio de organizações não-governamentais leigas, seja por entidades religiosas, como o Cimi, por exemplo. Embora esta última entidade tenha se esforçado para conduzir o movimento indígena, pelo menos em seus primórdios, tal não se consolidou, o que fez com que o movimento não chegasse a perder sua indispensável autonomia. Uma autonomia, por sinal, que teriam de conservar diante de quaisquer partidos políticos que eventualmente desejassem se associar ao movimento indígena, e ainda - e sobretudo - em relação ao Estado - e isso no caso da FUNAI vir a apoiar financeiramente a consolidação do campo indígena como a única instância possível de diálogo político legítimo. E, conseqüentemente, criando condições para a emergência de uma comunidade de comunicação e de argumentação interétnica, nos termos pelos quais entendo ser viável esse mesmo diálogo.

Pois como se viu na relação entre o Estado e as etnias indígenas pelo exame do modelo de etnodesenvolvimento e de seus pressupostos éticos, também aqui há de se considerar a possibilidade de se criar condições para a emergência de uma verdadeira comunidade de comunicação constituída pelas partes envolvidas pela conjunção interétnica e, com ela, uma comunidade de argumentação intercultural, capaz de assegurar a moralidade de suas práticas. As possibilidades de efetivação de uma tal comunidade assim ampliada, não mais interpares, mas entre partes com interesses eventualmente distintos, estaria na formulação e aplicação de uma política pública, governamental, voltada para uma negociação democrática com as lideranças indígenas. Teoricamente se poderia contar com a possibilidade do surgimento no interior dessa nova comunidade de comunicação de um nexo comum, ou de um saber fruto de uma "fusão de horizontes" (esse conceito tão caro à hermenêutica), onde as partes estabeleçam um universo mínimo de regras que assegurem a livre e produtiva interlocução. E não será nunca demais lembrar que mesmo com a natural ocorrência de discordâncias manifestadas na discussão elas já pressupõem, tacitamente, um acordo de base, a saber, a disposição de dialogar. 

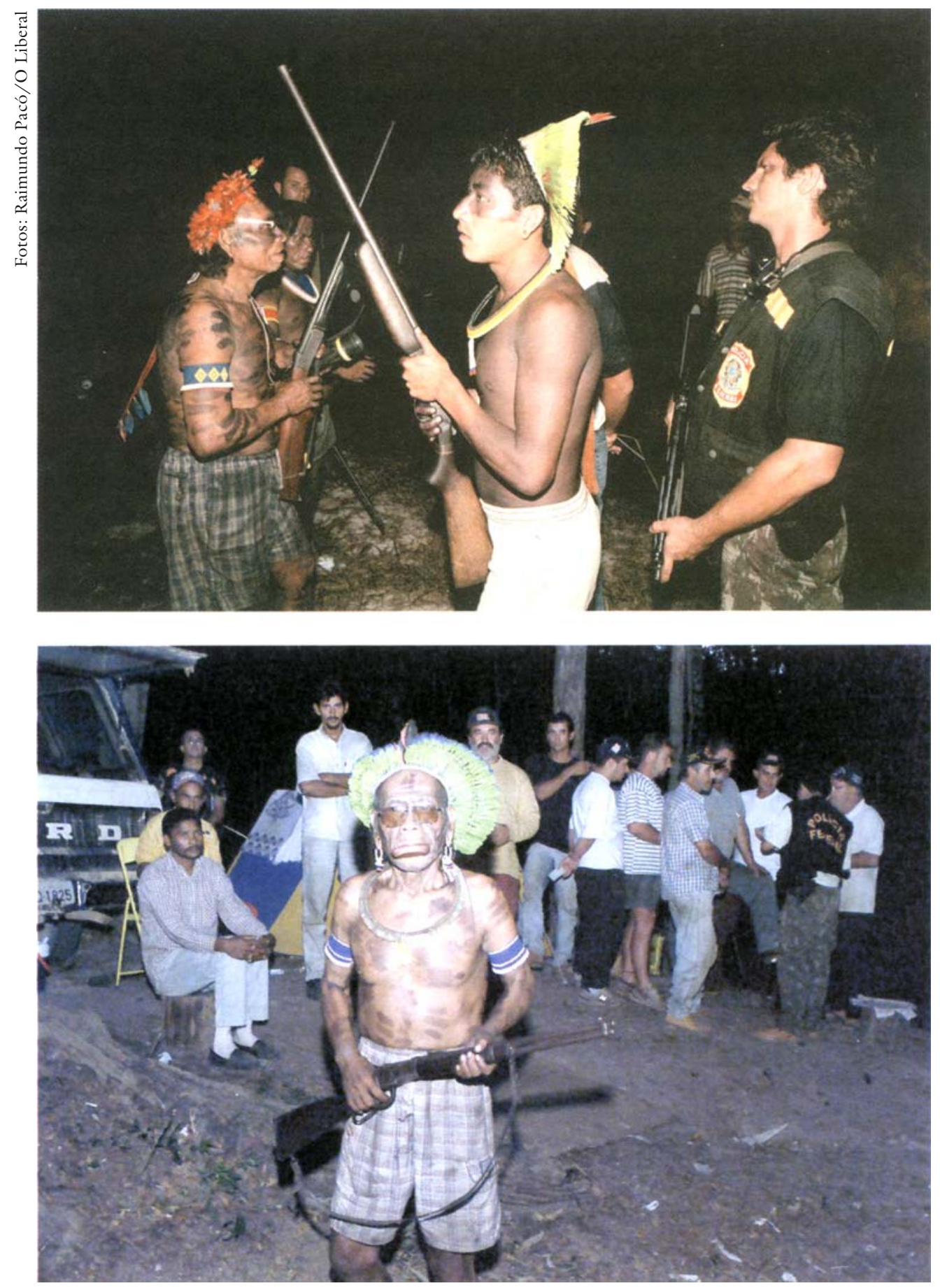

O cacique Raoni, chefe da tribo caiapó, foi flagrado de fuzil em punho enquanto comandava um grupo de índios armados de espingardas que mantinham como reféns 16 pescadores acampados às margens do rio Curuá, perto da cidade de Novo Progresso, no sudoeste do Pará. O episódio ocorreu no último dia 26 de julho. O grupo foi libertado depois de sete dias com a chegada da Polícia Federal e da Funai ante a promessa do governo de demarcar a reserva indígena Baú, de $18.500 \mathrm{~km}^{2}$. 


\section{Ação indigenista e eticidade}

Pois bem: com a organização do campo político indígena, é de se esperar que fiquem asseguradas as condições de interlocução no interior de uma comunidade de comunicação interétnica. Uma comunicação que se dá a partir da identificação de interlocutores representativos dos dois campos em interação potencialmente litigiosa: o campo indigenista e o campo indígena; podendo o litígio ser real ou virtual, não importa; o certo é que se trata de relações entre litigantes voltados para a busca de consenso pela via da argumentação. Nesse sentido, é incontornável o fato de que se trata, em princípio, da articulação prática de horizontes semânticos antagônicos. E não apenas por estarem condicionados por interesses diferentes, quando não sejam muitas vezes claramente antagônicos. Mas também pela distância cultural (ou "cultural lag", no jargão antropológico), que marca a diferença entre culturas, i.é entre o mundo indígena e o nacional. Será possível que

\section{poderão surgir práticas indigenistas suscetíveis de viabilizar esse diálogo ...} em algum momento de uma interlocução entre indivíduos ou grupos inseridos em campos semânticos incomensuráveis (ou culturas radicalmente distintas) possam eles chegar a algum tipo de acordo? É viável realizar-se na prática uma verdadeira fusão de horizontes? Muito se poderia discutir aqui com referência à teoria apeliana-habermasiana da ética do discurso. Porém, vou me limitar apenas a apontar algumas dificuldades que parecem ser inerentes ao diálogo interétnico. Pois sem a consideração dessas dificuldades dificilmente poderão surgir práticas indigenistas suscetíveis de viabilizar esse diálogo. Gostaria de pelo menos apontar uma dessas dificuldades, já que enumerá-las e examiná-las, uma a uma, iríamos além do tempo de uma conferência. Fiquemos aqui com a dificuldade que considero a principal: o comprometimento do diálogo pelas regras do discurso hegemônico; a saber, em se tratando das relações índio e não-índio, a hegemonia das regras institucionalizadas do discurso do pólo dominante sobre o pólo dominado, do não-índio sobre o índio.

Examinemos um pouco mais isso. E aqui reproduzo argumentos de que já me vali em outra oportunidade (8), mas que me parecem apropriados para evocá-los neste contexto. Vamos imaginar que todo diálogo entre índios e não-índios, que produza resultados de valor legal, tenha lugar através da FUNAI, o braço indigenista do Estado brasileiro. Em seu papel de mediadora nesse diálogo imaginário entre litigantes índios e não-índios, a FUNAI teria, em primeiro lugar, de interpretar o discurso indígena a fim de torná-lo 
não só audível, mas inteligível ao interlocutor alienígena. A exigência teórica da ética discursiva de uma argumentação racional, como característica básica de qualquer comunidade de comunicação, sempre guardaria um resíduo de ininteligibilidade, resultante da distância cultural entre as partes - mesmo no caso de ser a própria FUNAI parte interessada na solução de um impasse qualquer no contexto de um programa de etnodesenvolvimento, portanto voltado para auscultar a população indígena. Isso implicaria, por parte da FUNAI, exercitar o princípio da tolerância, naturalmente não como caridade, mas em obediência a um simples postulado de justiça (9). O problema ético, todavia, surgiria a partir do momento em que os índios encontrariam dificuldade em interpelar a FUNAI sobre o alcance das mudanças previstas por seu programa de mudança econômica e/ou social em nível micro, ou sobre a orientação da política indigenista, portanto governamental, conduzida em nível macro. A rigor, tal interpelação é um "ato de fala" dirigido pelo componente dominado da relação interétnica ao componente dominante - esse alienígena, culturalmente eurocêntrico e historicamente colonizador - que não pode cobrar do primeiro (do indígena) a obediência aos pré-requisitos de inteligibilidade, verdade, veracidade e retidão-pressupostos da ética discursiva - que se espera estejam presentes no exercício pleno do diálogo interétnico. Essa interpelação feita pelo índio ao nãoíndio dominador (que não é apenas representante do pólo politicamente dominante, mas também como alguém que domina a linguagem do discurso) torna muitas vezes difícil a inteligibilidade da mesma interpelação e, com ela, sua natural pretensão de validade, uma vez que falta aquela condição básica para o proferimento de um ato de fala que seja "verdadeiro" (isto é, aceito como verdadeiro pelo ouvinte alienígena); que tenha "veracidade", sendo portanto aceito como força ilocucionária (i.é, de convicção) pelo mesmo ouvinte; e que manifeste "retidão" ou, em outras palavras, que cumpra as normas da comunidade de argumentação eticamente constituída, normas estas estabelecidas (e institucionalizadas) nos termos da racionalidade vigente entre os não-índios, i.é no pólo dominante da relação interétnica. Essa institucionalidade dominadora tem sido, a rigor, senão a causa, pelo menos um sério fator de infelicidade do pólo dominado, incapaz de ser eludida pelos indigenistas militantes, seja do setor oficial ou do alternativo constituído pelas ONGs e pelas missões religiosas. Isso significa que na relação entre indígenas e alienígenas, mediada ou não pelo Estado (entenda-se FunAI), mesmo se formada uma comunidade interétnica de comunicação e de argumentação, e que pressuponha relações dialógicas democráticas (pelo menos na intenção do pólo dominante), mesmo assim $o$ diálogo estará comprometido pelas regras do discurso hegemônico. Essa situação somente estaria superada quando o índio interpelante pudesse, através 
do diálogo, contribuir efetivamente para a institucionalização de uma normatividade inteiramente nova, fruto da interação havida no interior da comunidade intercultural. Em caso contrário - para falarmos como Habermas - persistiria uma espécie de "comunicação distorcida" entre índios e nãoíndios, comprometedora da dimensão ética do discurso argumentativo. Porém, na ausência de uma nova normatividade, teoricamente possível, mas de difícil realização na prática (pelo menos diante da realidade atual não só no Brasil, mas no mundo), o horizonte não está de todo sombrio se considerarmos a probabilidade do domínio do discurso hegemônico pelo pólo dominado da relação interétnica.

As imensas dificuldades de institucionalização de uma nova normatividade pelo pólo dominado, ou vitimado pelo colonialismo interno, podem ser em grande parte superadas graças ao domínio crescente da linguagem dominante (ou do discurso hegemônico) por lideranças indígenas não só no país, como já se tem observado, como em outros países americanos, como o caso dos náuas mexicanos há pouco mencionado ilustra bastante bem! E isso pode ser explicado pela significativa presença que se pode constatar no diálogo interétnico de lideranças indígenas, intelectualizadas ou não, porém bastante hábeis em se orientar no interior do discurso político nacional, como recentemente pudemos observar numa assembléia dos Tükúna, realizada no alto rio Solimões, onde com muita clareza expuseram suas reivindicações sobre o seu direito à terra, à saúde e à educação (10). E um outro exemplo que pode ser evocado aqui e de cuja singularidade em nosso país nos leva a imaginar que talvez estejamos diante de um quadro interétnico excepcional no que tange a entendimentos políticos entre diferentes etnias situadas no interior de um mesmo território indígena. Refirome à Reserva Indígena do Uaçá, junto da fronteira do Brasil com a Guiana Francesa no estado do Amapá. Dividem a ocupação da área três etnias, a Palikur, a Galibi e a Karipuna. Embora seja um território controlado pela FUNAI, todos os postos indígenas são dirigidos por encarregados pertencentes a uma dessas etnias, observando-se ainda casos em que um determinado chefe de posto pode tornar-se responsável por uma aldeia de uma etnia diferente da sua, o que chega a ser surpreendente! Isso revela um elevado grau de entendimento político entre lideranças que, por sua vez, se submetem periodicamente ao escrutínio das assembléias indígenas. Contra o esteriótipo de que "os índios não se entendem", esse me parece ser um bom exemplo sobre a possibilidade de obtenção de consenso entre etnias indígenas de maneira a assegurar a viabilização de representação política em nível regional e, quem sabe, em nível nacional junto ao Estado-nação; uma representação destinada a negociar a formulação de uma política indigenista que atenda às demandas de uma política indígena. Esse caso da Reserva Indígena 
do Uaçá aponta para essa possibilidade. E ainda caberia registrar - no que diz respeito ao diálogo externo à Reserva - que as novas gerações são praticamente alfabetizadas e com graus razoáveis de instrução, o que faz dos novos líderes pessoas que dominam bastante bem as normas do discurso regional, uma vez que vários deles já ocupam cargos administrativos na FUNAI ou mesmo políticos no município de Guaporé, como o de prefeito ou de vereador. Ademais há de se assinalar a criação de sua própria organização denominada "Associação dos Povos Indígenas do Uaçá" que, como já foi mencionado, comprova a capacidade associativa das etnias indígenas e de sua eficácia na ocupação de um espaço político que lhes permita uma efetiva interlocução com o Estado-nação (11).

Portanto, o que se vê atualmente é que em diferentes partes do nosso hemisfério começam a surgir líderes indígenas bastante competentes no uso da linguagem do pólo dominante, fato reconhecido em nível do hemisfério pelo Instituto Indigenista Interamericano (12); i.é, muito mais do que conhecedores do idioma português, inglês, francês ou espanhol, essas lideranças são capazes de se movimentar no interior das normas do discurso hegemônico, o que lhes permite conduzir uma argumentação audível e inteligível no interior do campo indigenista, sem serem obrigados a institucionalizar uma nova normatividade sustentadora do diálogo interétnico - algo bem mais difícil de se alcançar. Mas se isso não é tudo (pois in-

"O que nós quevemos é aprender o regulamento dos civilizados ..." felizmente fica sempre marginalizada

desse diálogo a grande maioria da população indígena), também isso não é pouco, se considerarmos que é um fato que deve mostrar um rumo para uma política indigenista voltada para preparar o índio a se tornar um competente interlocutor e não um mero cliente de eventuais benesses do Estado ou mesmo de segmentos da sociedade civil. E isso vem ao encontro do interesse indígena. Lembro-me que nos primeiros contatos que tive com o povo Terêna - ao tempo em que era etnólogo do SPI, isso em meados dos anos 50 -, conheci o "Capitão" Timóteo, líder da aldeia Cachoeirinha, ou Bookoti - como é conhecida em idioma Chané -, e dele ouvi a seguinte reivindicação: "O que nós queremos é aprender o regulamento dos civilizados..." Certamente ele falava pelo povo, sobretudo pelos jovens com quem eu sempre conversava ao cair da noite, deles ouvindo a mesma reivindicação; era quando o termo "regulamento" assumia a sua mais ampla significação: a de desejarem se inteirar das formas de vida da população regional e urbana com quem eram obrigados a conviver, graças à migração para $\mathrm{o}$ trabalho que realizavam fora da reserva indígena a fim de complementarem 
suas economias de subsistência; e, não há dúvida, que dentre essas formas a que mais despertava interesse eram as normas do discurso alienígena, falado por seus patrões virtuais, cujo domínio lhes parecia indispensável para assegurar uma comunicação competente no interior desse discurso. O domínio da linguagem e, através dela, a penetração no discurso hegemônico parecia ao Terêna já naquela época - quando o tema da cidadania não tinha o destaque que tem hoje - um imperativo de uma interação cultural altamente positiva, pois condição de aprimoramento do diálogo interétnico e, naturalmente, de democratização das relações entre índios e não-índios. Nesse sentido, o Terêna Timóteo, com sua fala, constitui aqui uma verdadeira metáfora humana dessa incansável busca de compreensão do Outro (e aqui o Outro é o alienígena que se autoproclama "civilizado") e de - por ele ser compreendido, que os povos indígenas no Brasil, na América Latina e nas mais diferentes latitudes do planeta, têm enfrentado em sua contínua luta pela sobrevivência. É mister que pelo menos em nosso país essa compreensão não lhes falte.

\section{Conclusão}

É hora de concluir. Com os três problemas aqui examinados - o do etnodesenvolvimento, o da constituição do campo político indígena como pressuposto à institucionalização de uma ética na ação indigenista e o das condições de viabilidade do diálogo interétnico - procurei contribuir para equacionar alguns impasses que acredito típicos neste limiar desse novo século na esfera dos confrontos étnicos, isto é, os que têm lugar no interior de um mesmo país multiétnico. São problemas que revelam a necessidade de o campo indigenista assumir o diálogo interétnico e intercultural como fator decisivo na promoção da cidadania indígena. E ao assumir esse desafio, não se pode deixar de levar em conta as dificuldades inerentes à implementação desse mesmo diálogo. E, nesse sentido, reconhecer igualmente que sob a dimensão política, habitualmente vista apenas pela ótica da democratização, haveria também de invocar a questão da eticidade, onde predomina - como uma de suas dimensões constitutivas - a ética do discurso aqui examinada com alguma insistência. É assim que entendo como a prática indigenista possa ser simultaneamente crítica e autocrítica, desde que baseada no reconhecimento da importância das comunidades de comunicação e de argumentação de perfil interétnico. Isso certamente contribuiria para que tempos melhores cheguem aos povos originários e que o Estado, além dos princípios democráticos que sempre deve orientá-lo, também atenda aos preceitos de moralidade na condução do diálogo entre índios e nãoíndios. 
Notas

1 Num trabalho anterior (O Saber, a Ética e a Ação Social, in: Manuscrito: Revista Internacional de Filosofia, v. XIII, n. 2, p. 7-22, 1990), refiro-me à "Declaração de San José" resultante da mesma reunião, da qual tive a oportunidade de participar, onde tal política está formulada. Naquele trabalho pude explorar o conceito de etnodesenvolvimento com o objetivo de mostrar em que medida o problema ético lhe é inerente, ao mesmo tempo em que mostro como a ética está igualmente associada à construção do conhecimento.

2 Tenho me valido desses mesmos argumentos em Cardoso de Oliveira (1992 e 1998, cap. 9), onde estão mais amplamente desenvolvidos.

3 Cf. R.Cardoso de Oliveira [1964], 1996, cap. V.

4 Como referência gostaria de mencionar a quem se interessar por esse importante debate, textos de Gadamer e de Habermas, incluindo ainda um de Paul Ricoeur com instrutivos comentários sobre a interessante controvérsia. Nesse sentido, cf. Gadamer, 1982 [original alemão 1960] e 1971; Habermas, 1970; Ricoeur, 1973.

5 No trabalho citado na nota 3 pude me louvar na teoria do etnodesenvolvimento para com ela ilustrar a existência de uma dimensão ética, como pressuposto de um acordo interétnico negociado entre as partes envolvidas num processo de transformação social induzida. Agora, ao retomá-la, estou procurando aprofundar melhor a natureza desse acordo e de suas implicações especificamente no interior do indigenismo.

6 Stavenhagem apresenta seis características ou princípios como inerentes ao modelo. Para uma leitura completa do texto relativo ao assunto, ler Stavenhagem, 1985, passim.

7 Cf. L.D.B. Grupioni, 1999.

8 Cf. R. Cardoso de Oliveira, Etnicidade, Eticidade e Globalização, in: O Trabatho do Antropólogo, Brasília, Paralelo 15 / Editora Unesp, 1998, cap. 9.

9 Cf. meu artigo Sobre o Diálogo Intolerante, in: O Trabalho do Antropólogo, cap. 10, op. cit.

10 Tomei conhecimento do evento através do Video "Uma Assembléia Ticuna" realizada sob a direção de Bruno Pacheco de Oliveira e coordenação de João Pacheco de Oliveira (Museu Nacional).

11 Uma recente etnografia da Reserva Indígena do Uaçá está desenvolvida em Musolino, A.A.N., 1999.

12 Cf. Instituto Indigenista Interamericano, 1990, p. 80. 
Referências bibliográficas

APEL, K-O. La transformación de la filosofia, t. II. Madri, Tauros. 1985.

CARDOSO DE OLIVEIRA, R. O indio e o mundo dos brancos [1964], 4ª ed. Campinas, Editora da Unicamp, 1996. . A crise do indigenismo. Campinas, Editora da Unicamp, 1988. O saber, a ética e a ação social. Manuscrito - Revista Internacional de Filosofia, v. XIII, n. 2, p. 7-22, 1990. Indigenismo e moralidade. Tempo Brasileiro, 111, p. 5-20, 1992. da Unesp, 1998.

O trabalho do antropólogo. Brasília, Editora Paralelo 15 / Editora

GADAMER, H-G. Truth and method. Nova Iorque, The Crossroad Publish. Co., 1982.

Rhétorique, herméneutique et critique de l'idéologie: commentaires métacritiques de Wabrheit und Methode. In: Archives de Philosophie, 34, p. 207-230, 1971.

GRUPIONI, L.D.B. Diretório de associações e organizações indígenas no Brasil. Brasília, INEP, 1999.

HABERMAS, J. A review of Gadamer's: truth and method. In: Zur Logik der Sozialwissenschaften, p. 251-290. 1970.

HERNÁNDEZ, N. Reflexiones en torno al etnodesarrollo como principio y como meta dentro de la pluralidad étnica del pais. In: Lourdes Arizpe \& Ludka Gortari (orgs.), Repensar la nación: fronteras, etnias y soberania. México, Cuadernos de la Casa Chata 174 / CIESAS / SEP, 1990, p. 67-70.

INSTITUTO INDIGENISTA INTERAMERICANO. Política indigenista (19911995). América Indígena, v. L, p. 7-139, 1990.

MUSOlinO, A.A.N. A estrela do Norte: Reserva Indigena do Uaçá. Campinas, 1999. Dissertação (mestrado). Dep. de Antropologia da Unicamp [mimeo.].

RICOEUR, P. Hermenéutique et critique des idéologies. In: E. Castelli (org.), Démythisation et ideologie. Paris, Aubier, 1973, p. 25-61.

STAVENHAGEN, R. Etnodesenvolvimento: uma dimensão ignorada do pensamento desenvolvimentista. Anuário Antropológico, 84, p. 11-44, 1985.

Roberto Cardoso de Oliveira é professor emérito da Unicamp e pesquisador visitante na Universidade de Brasília.

Conferência feita pelo autor na $52^{\text {a }}$ Reunião da SBPC, realizada em Brasília (DF) no período de 9 a 14 de julho de 2000 . 